\title{
Rancang Bangun Sistem Pakar untuk Deteksi Dini Katarak Menggunakan Algoritma C4.5
}

\author{
Ivana Herliana W. Jayawardanu, Seng Hansun \\ Program Studi Teknik Informatika, Universitas Multimedia Nusantara, Tangerang, Indonesia \\ theresia.ivana08@gmail.com, hansun@umn.ac.id
}

Diterima 4 November 2015

Disetujui 30 Desember 2015

\begin{abstract}
In 2010, 51\% of 39 million blindness are caused by cataract. In 2013, there are $1.8 \%$ of 1.027.763 Indonesian people who suffered from cataract. Half of them are not treated yet due to their ignorance on the cataract disease. Therefore, in this research, we tried to build a system that can detect early cataract disease as the ophthalmologist would do. The system will use $C 4.5$ algorithm that receives 150 training data set as an input, resulting in a set of rules which can be used as decision factors. To test the system, $k$-fold cross validation technique is been used with $k$ equals to 10 . From the analysis result, the accuracy of the system is $93.2 \%$ to detect cataract disease and $\mathbf{8 0 . 5 \%}$ to detect the type of cataract disease one might suffered.
\end{abstract}

Index terms-C4.5 algorithm, cataract, k-fold cross validation, machine learning

\section{PENDAHULUAN}

Banyak faktor yang dapat menyebabkan kebutaan mata. Menurut World Health Organization $[1,2]$ penyebab $51 \%$ dari 39 juta kebutaan yang terjadi pada tahun 2010 di seluruh dunia adalah penyakit mata katarak. Berdasarkan Riset Kesehatan Dasar yang dilakukan pada 1.027.763 orang, tingkat kebutaan di Indonesia pada tahun 2013 mencapai 0,4\% [3]. Dalam Riskesdas juga disebutkan dari populasi tersebut, penderita katarak di Indonesia pada tahun 2013 sebesar 1,8\%. Separuh dari penderita katarak tersebut belum menjalani pengobatan katarak dikarenakan faktor ketidaktahuan penderita mengenai penyakit mata yang dideritanya [3].

Hal yang dilakukan untuk meminimalisir ketidaktahuantersebut adalah dengan membangun sebuah sistem yang dapat mendeteksi katarak secara dini tanpa harus mengunjungi klinik mata. Sistem ini dibangun berbasiskan website, dengan mengimplementasikan metode learning decision tree dengan algoritma C4.5. Algoritma C4.5 dipilih karena dinyatakan sebagai algoritma learning yang memiliki tingkat keakurasian paling tinggi pada penelitian yang berjudul "Analisis Komparasi Algoritma Klasifikasi Data Mining untuk Prediksi Mahasiswa Non Aktif" [4].

\section{LANDASAN TEORI}

\section{A. Artificial Intelligence}

Istilah AI pertama kali dikemukakan pada tahun 1956 di konferensi Darthmouth, oleh John McCarthy [5]. Terdapat empat (4) teknik pemecahan masalah yang dapat dikembangkan secara terpisah atau dipadukan secara bersama, yaitu: searching, reasoning, planning, dan learning. Penelitian AI berkembang menjadi tiga (3) domain seperti pada Gambar 1.

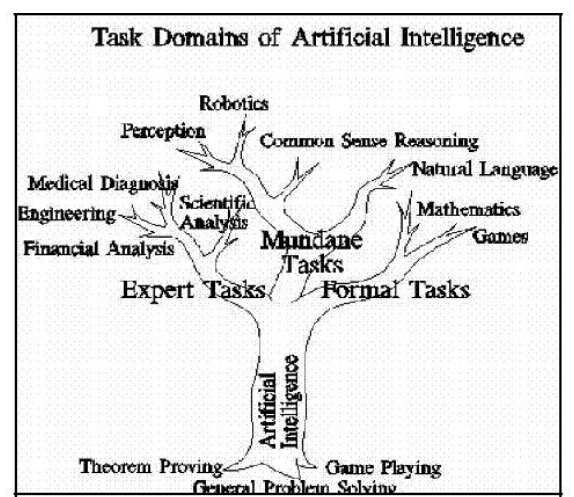

Gambar 1. Tasks Domains of Artificial Intelligence[6] 


\section{B. Sistem Pakar}

Sistem pakar merupakan cabang dari AI yang memiliki knowledge base. Sistem pakar dapat bekerja sesuai dengan pengetahuan pakar yang dimasukkan ke dalamnya [7]. Pengetahuan tersebut diproses menggunakan algoritma yang ada untuk menghasilkan rules. Rules tersebut dijadikan dasar dalam menentukan hasil akhir dari setiap data yang diuji.

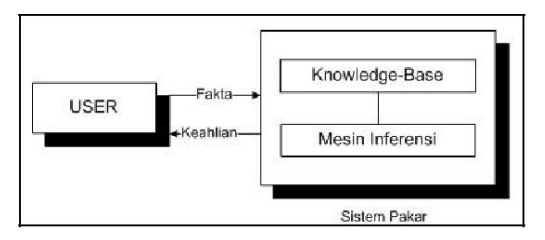

Gambar 2. Konsep dasar sistem pakar [8]

Konsep dasar sistem pakar dapat digambarkan seperti pada Gambar 2, sehingga dapat dijelaskan sebagai berikut:

\section{User}

Terdapat tiga (3) komponen user yang terlibat di dalam environment system [9], yaitu:

a. Pakar, yaitu seorang ahli yang dipercayai pendapatnya karena memiliki pengetahuan khusus dan spesifik.

b. Perekayasa sistem (Knowledge Engineer), yaitu seorang engineer yang menganalisis, merancang, dan membangun sistem.

c. Pengguna (User), yaitu orang awam yang menggunakan sistem.

\section{Knowledge Base}

Knowledge base berisi pengetahuan yang dapat digunakan dalam mendapatkan hasil dari sistem. Terdapat dua (2) pendekatan yang dapat digunakan dalam membangun sistem, yaitu: rule-based reasoning dan casebased reasoning.

3. Mesin Inferensi

Mesin inferensi mengandung mekanisme pola pikir dan penalaran yang digunakan oleh pakar dalam menyelesaikan suatu permasalahan.

\section{Data Mining}

Data mining adalah proses mempekerjakan satu atau lebih teknik machine learning untuk menganalisis dan mengekstraksi knowledge secara otomatis [10]. Penggunaan data mining memiliki tujuan untuk mengetahui pola universal dari data-data yang ada. Dalam menghasilkan suatu knowledge dari pola yang ada, diperlukan penerapan metode scientific yang disebut dengan Knowledge Discovery in Database (KDD).

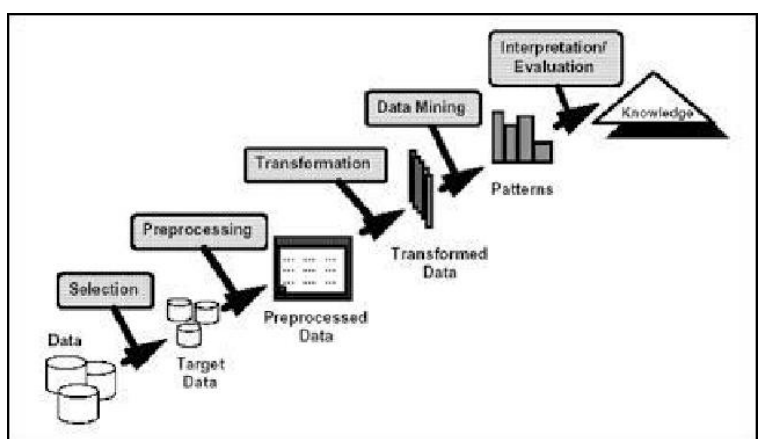

Gambar 3. Tahapan proses KDD [10]

Dorian Pyle pada bukunya Data Preparation for Data Mining, mengestimasi bahwa tahapan persiapan data pada KDD membutuhkan 60\% dari keseluruhan waktu pemrosesan data [11]. Tahap pada proses KDD adalah sebagai berikut [10]:

\section{Selection}

Pertama, lakukan seleksi data dari multiple data source dengan membersihkan data yang memiliki noise ataupun missing value.

2. Preprocessing

Kedua, lakukan penggabungan terhadap seluruh data source yang telah terkumpul sebelum tahapan dari proses selanjutnya dilanjutkan.

3. Transformation

Ketiga, lakukan transformasi data ke dalam bentuk yang lebih sesuai untuk dilakukan 
data mining.

\section{Data Mining}

Keempat, terapkan metode data mining pada sistem, sehingga dapat menghasilkan pola dari data yang terkumpul.

5. Interpretation/Evaluation

Kelima, lakukan interpretasi dan evaluasi dari pola yang didapatkan, sehingga dapat diidentifikasi apakah pola tersebut sudah dapat mewakili knowledge yang ingin dicapai.

\section{Klasifikasi}

Klasifikasi adalah salah satu teknik data mining yang mengelompokkan data menjadi berbagai kelas data dengan tujuan memprediksi kelas untuk data yang tidak diketahui kelasnya. Dalam klasifikasi terdapat dua (2) tahapan yang harus dilalui. Tahap pertama adalah induksi, yaitu: pembangunan model sebagai prototype untuk disimpan. Tahap kedua adalah deduksi, yaitu: penggunaan model yang dihasilkan untuk melakukan klasifikasi, pengenalan, dan prediksi pada suatu objek data lain agar diketahui termasuk kelas manakah objek data tersebut tergolong di dalam memori [12].

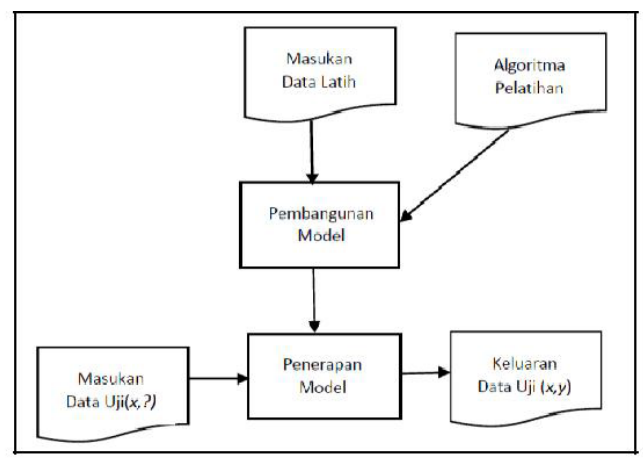

Gambar 4. Tahapan Data Mining [12]

Dalam menggunakan teknik klasifikasi diperlukan suatu algoritma pelatihan untuk mendapatkan suatu model yang paling memenuhi hubungan antara himpunan nilai dari setiap variable dengan hasil. Salah satu metode learning yang dapat digunakan adalah decision tree.

\section{E. Decision Tree}

Decision tree adalah sebuah struktur data yang terdiri dari kumpulan node yang saling terhubung melalui edge. Simpul pada sebuah pohon dibedakan menjadi: root, branch, dan leaf. Decision tree dapat merepresentasikan secara sederhana teknik klasifikasi untuk sejumlah kelas berhingga, dimana simpul cabang maupun simpul akar ditandai dengan nama atribut, sementara setiap rusuknya diberi label nilai dari atribut tersebut (record) [10]. Dalam mendapatkan solusi, tahapan yang harus dilakukan adalah mengelompokan set-data ke dalam tabel, lalu mengubah tabel tersebut menjadi bentuk pohon dengan menggunakan algoritma yang ditentukan, kemudian mengubah model pohon menjadi rules [13].

\section{F. Algoritma $C 4.5$}

Algoritma C4.5 merupakan pengembangan dari algoritma ID3 yang dilakukan Quinlan [14]. Algoritma ini dapat menyelesaikan masalah secara sistematis dengan membentuk suatu decision tree dengan langkah-langkah sebagai berikut:

1. Pilih atribut sebagai akar,

2. Buat cabang untuk masing-masing record dari atribut,

3. Membagi kasus ke dalam cabang,

4. Ulangi proses untuk masing-masing cabang sampai semua kasus pada cabang menghasilkan suatu keputusan yang sesuai.

Dalam memilih sebuah atribut menjadi akar, dilakukan perhitungan nilai dari atribut yang ada. Nilai gain yang paling tinggi dijadikan root pada pohon keputusan. Untuk menghitung nilai gain digunakan rumus:

$$
\operatorname{Gain}(S, A)=\operatorname{Entropy}(S)-\sum_{1}^{n} i \frac{\left|S_{i}\right|}{|S|} x \operatorname{Entropy}\left(S_{i}\right) \quad \ldots \text { Rumus } 2.1
$$

dengan

$$
\begin{aligned}
& \text { : himpunan kasus } \\
& \text { : atribut } \\
& \text { : jumlah partisi atribut A } \\
& \text { : jumlah kasus pada partisi ke-i }
\end{aligned}
$$


Sedangkan untuk perhitungan nilai entropy dapat dilakukan dengan rumus:

$\operatorname{Entropy}(S)=-\sum_{1}^{n} i p_{i} x \log _{2} p_{i}$ Rumus 2.2

dengan:

$\mathrm{S}$ : himpunan kasus

$\mathrm{n}:$ jumlah partisi $\mathrm{S}$

pi: proporsi dari Si terhadap $\mathrm{S}$

Setelah perhitungan selesai, maka dihasilkan pohon keputusan yang dapat diubah menjadi rules menggunakan kaidah IF-THEN-ELSE.

\section{G. Katarak}

Katarak adalah Bahasa Yunani, Katarrhakies yang berarti air terjun. Katarak merupakan suatu kelainan pada mata dimana lensa mata terlihat keruh [15]. Kekeruhan lensa dapat terjadi pada saat perkembangan serat lensa masih berlangsung atau sesudah serat lensa berhenti perkembangannya [16]. Faktor yang dapat menyebabkan seseorang mengalami katarak adalah [17]:

1. Usia

2. Cedera Mata

3. Penyakit Sistemik

4. Radiasi Sinar Ultraviolet

5. Campak (Infeksi Virus rubella)

6. Riwayat Keturunan

7. Riwayat Obat Steroid

Gejala yang dapat dialami oleh penderita katarak, antara lain:

1. Pandangan mata kabur

2. Perubahan dalam persepsi warna

3. Penglihatan ganda pada satu mata (Halo)

4. Penglihatan di malam hari lebih berkurang

5. Penglihatan menguning

6. Seperti ada titik gelap di depan mata

7. Susah untuk melihat di tempat yang terang karena silau

8. Pandangan kurang tajam

Jenis katarak berdasarkan penyebab katarak adalah [16]:
1. Katarak Primer

Katarak yang diklasifikasikan berdasarkan usia manusia.

a. Katarak Kongenital

Katarak yang terlihat pada usia di bawah 1 tahun.

b. Katarak Juvenilis

Katarak yang terlihat pada usia di atas 1 tahun dan di bawah 40 tahun.

c. Katarak Presenilis

Katarak yang terjadi pada penderita di bawah 30 - 40 tahun.

d. Katarak Senilis

Katarak yang terjadi pada penderita berusia lebih dari 40 tahun.

\section{Katarak Sekunder}

Katarak sekunder dapat terjadi apabila penderita telah menjalani bedah lensa dan mengalami kekeruhan lensa kembali.

3. Katarak Komplikata

Katarak Komplikata adalah katarak yang dapat terjadi akibat adanya komplikasi dari penyakit lain, penggunaan obat steroid dalam jangka panjang, dan adanya cedera mata yang pernah dialami oleh penderita.

Katarak stadium awal, dapat diatasi dengan menggunakan kacamata. Apabila penderita merasa kataraknya sudah sangat mengganggu, maka diperlukan tindakan operasi [18].

\section{H. K-fold Cross Validation}

$K$-fold cross validation adalah teknik umum yang digunakan dalam mengestimasi performa dari teknik klasifikasi pada jumlah set-data yang kecil. Cara untuk melakukan teknik ini adalah dengan menentukan nilai $k$ yang digunakan sebagai ukuran pembagi set-data yang diuji. Penggunaan nilai $k$ terbaik untuk menguji validitas data training adalah sebesar 10 [19]. 


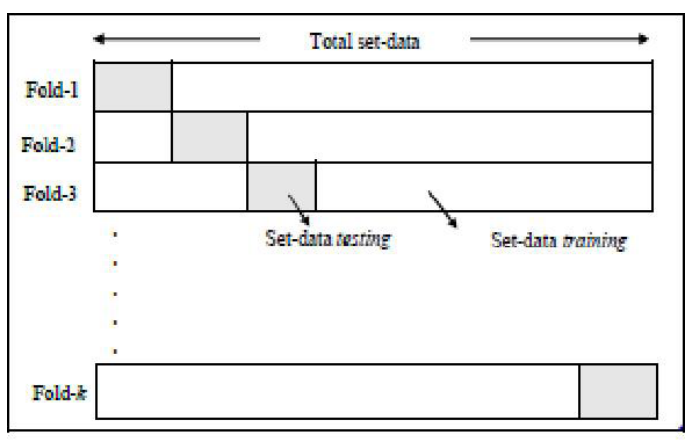

Gambar 5. K-fold cross validation [20]

\section{METODOLOGI PENELITIAN DAN PERANCANGAN SISTEM}

\section{A. Metodologi Penelitian}

Berdasarkan prinsip software process menurut Pressman [21], maka langkah-langkah yang dilakukan dalam pembangunan sistem ini adalah sebagai berikut:

1. Studi Literatur

Studi literatur dilakukan untuk memperdalam wawasan dan pengetahuan mengenai topik penelitian yang dilakukan secara valid, serta untuk mendapatkan gambaran mengenai topik yang diambil.

2. Pengumpulan Data

Pengumpulan data dilakukan dengan membuat dan memberikan form diagnosa kepada dokter spesialis mata untuk diisi.

3. Analisis Model Sistem

Pada tahap ini, dilakukan penentuan atribut decision tree yang digunakan dalam sistem. Selain itu, juga dilakukan analisis model sistem secara terstruktur.

4. Perancangan Sistem

Pada tahap ini, dilakukan perancangan user interface, perancangan database, dan perancangan alur sistem.

5. Pembuatan program
Program yang dibuat adalah berupa website dengan Bahasa pemrograman PHP dan database MYSQL.

6. Pengujian

Pengujian adalah proses pelatihan sistem yang telah dibuat secara spesifik, dalam menemukan error sebelum digunakan oleh pengguna.

7. Penarikan Simpulan

Tahapan terakhir adalah menarik simpulan dari hasil pengujian yang telah dilakukan.

B. Analisis Perancangan

Perancangan sistem pakar deteksi dini penyakit katarak ini menggunakan algoritma C4.5. Flowchart algoritma C4.5 digambarkan pada tiga (3) gambar 6.

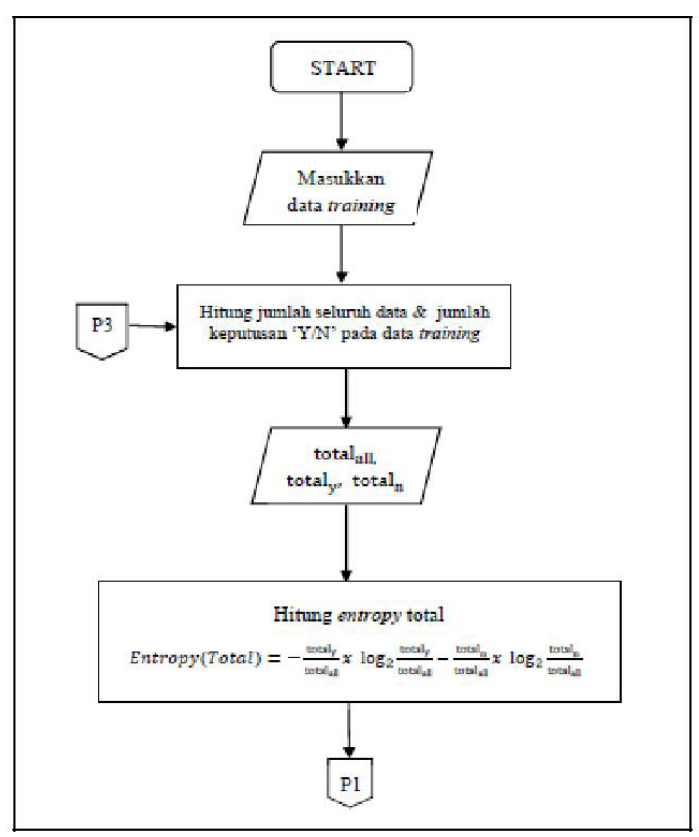

Gambar 6. Flowchart inisialisasi awal data training

Alur proses pada algoritma C4.5 pada sistem ini dimulai dengan memasukkan data training, kemudian dihitung jumlah data dan jumlah keputusan pada data training tersebut. Kemudian, hasil dari perhitungan dijadikan variable untuk menghitung entropy total, 
kemudian dilanjutkan ke P1.

Pada P1, pertama-tama dilakukan perhitungan jumlah record dan jumlah keputusan setiap record dari masing-masing atribut. Setelah itu, output yang didapatkan dijadikan variable untuk menghitung entropy dari masing-masing record. Setelah seluruh atribut telah diketahui jumlah record, jumlah keputusan setiap record, dan entropy record, maka dilanjutkan dengan menghitung nilai gain dari atribut dengan mengurangkan entropy (total) yang sudah didapat dengan probabilitas masing-masing hasil keputusan dikali entropy dari masing-masing record atribut tersebut. Jika seluruh atribut yang ada di dalam sistem telah dihitung nilai gain-nya, maka akan diteruskan ke P2.

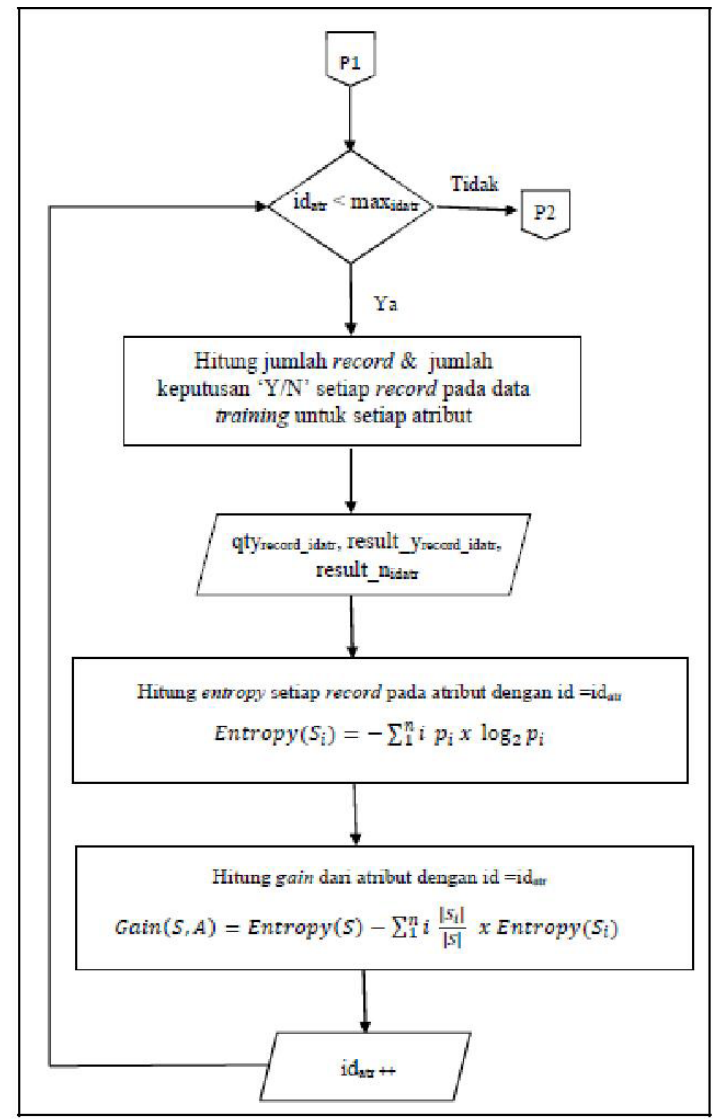

Gambar 7. Flowchart proses mendapatkan variabel yang dibutuhkan setiap record pada atribut
Pada P2, dilakukan pencarian maxgain. Jika gain dari suatu atribut tidak sama dengan maxgain, maka pencarian akan diulangi dengan mencari nilai gain dari atribut dengan id berikutnya sampai ditemukan bahwa gain dengan id atribut = idatr merupakan gain yang memiliki nilai gain tertinggi (maxgain). Atribut terpilih tersebut dijadikan sebagai node dari pohon keputusan, sementara record dari atribut tersebut sebagai leaf dari pohon keputusan. Kemudian, dilakukan pengecekan pada masingmasing record yang menjadi leaf, apakah entropy yang dimiliki record tersebut adalah 0 ? Jika 'Ya', maka leaf tersebut langsung menghasilkan sebuah keputusan. Jika 'Tidak', maka masuk ke dalam proses me-generate data training baru sesuai dengan kondisi dari node-leaf tersebut, kemudian dilanjutkan ke P3. Pada P3, dilakukan perhitungan jumlah data dan jumlah keputusan yang memenuhi kondisi node-leaf tersebut. Lalu, dilakukan kembali perhitungan entropy dan gain yang dilanjutkan dengan penentuan node berikutnya.

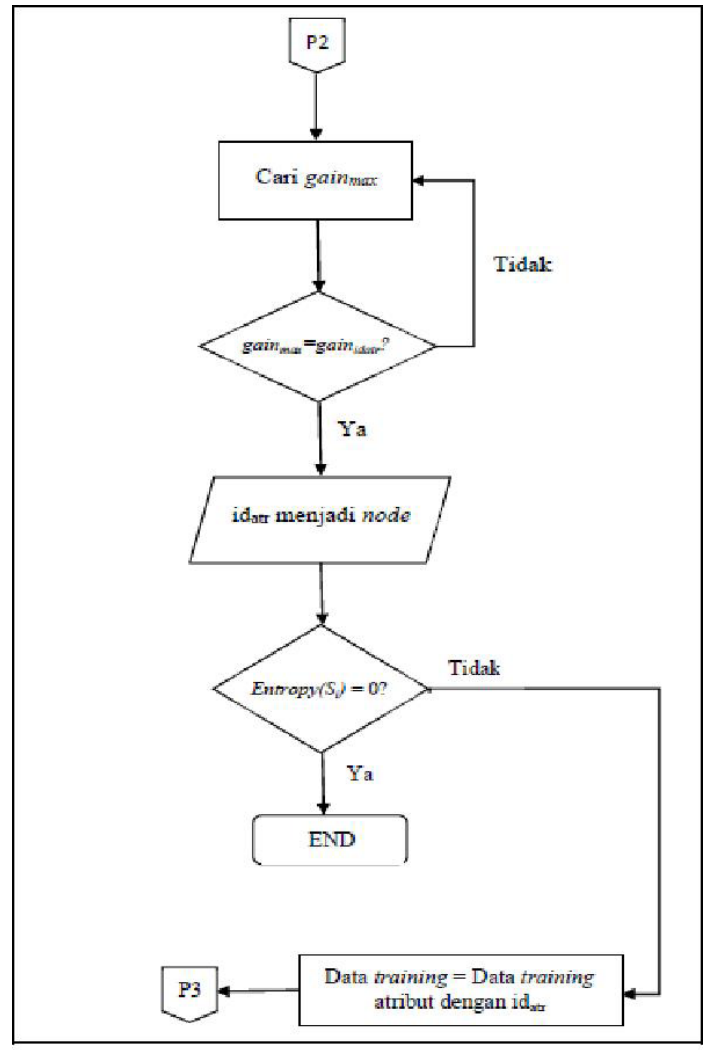

Gambar 8. Flowchart pembentukan node dari pohon keputusan 


\section{IMPLEMENTASI DAN UJI COBA}

Sistem yang dibangun dalam penelitian ini berupa sebuah website yang dibedakan menjadi bagian frontend dan backend. Berikut penjelasan hasil implementasi yang diterapkan pada masingmasing bagian.

\section{A. Frontend}

Terdapat empat halaman utama pada frontend website ini, yaitu:

1. Halaman Index

Halaman ini merupakan halaman utama yang ditampilkan saat user masuk pertama kali ke dalam sistem yang dibangun.

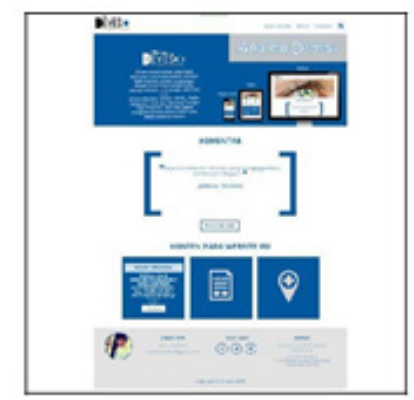

Gambar 9. Hasil implementasi halaman index dari frontend website

2. Halaman Diagnose

Tampilan halaman diagnose pertama kali adalah seperti pada Gambar 10. Visitor diminta untuk menginputkan nama dan lokasinya. Setelah itu, visitor dapat mengklik button 'Mulai', sehingga pop-up pertanyaan dapat muncul seperti pada Gambar 11.

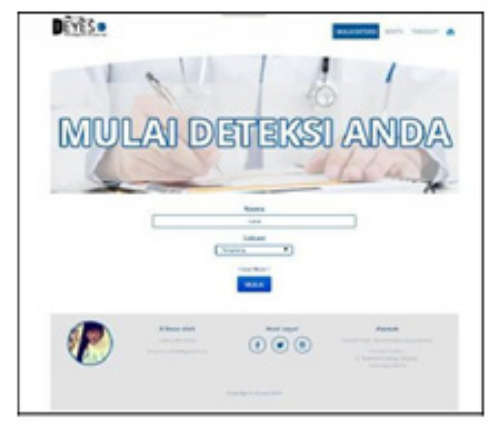

Gambar 10. Hasil implementasi halaman diagnose dari frontend website

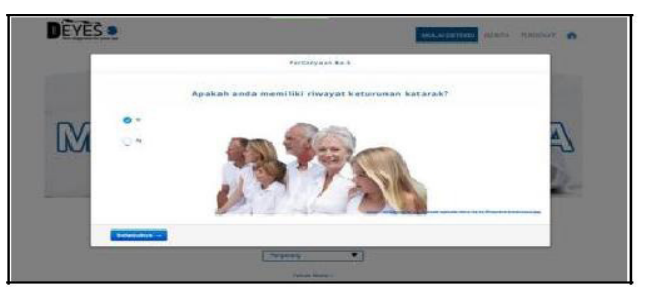

Gambar 11. Pop-up pertanyaan pada halaman diagnose frontend website

3. Halaman News

Pada halaman news, visitor dapat melihat berbagai berita yang terakhir di-posting. Tampilan halaman news dapat dilihat pada Gambar 12.

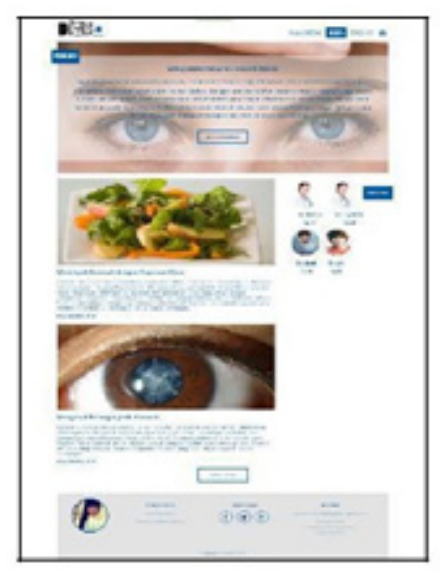

Gambar 12. Hasil implementasi halaman news dari frontend website

4. Halaman Nearby

Tampilan halaman nearby pertama kali adalah seperti pada Gambar 13.

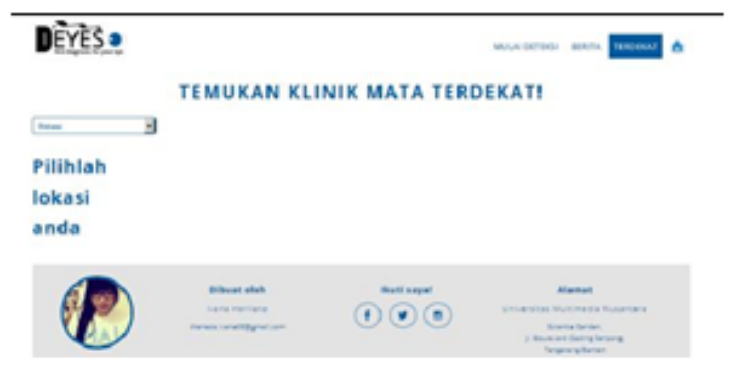

Gambar 13. Hasil implementasi halaman nearby dari frontend website 


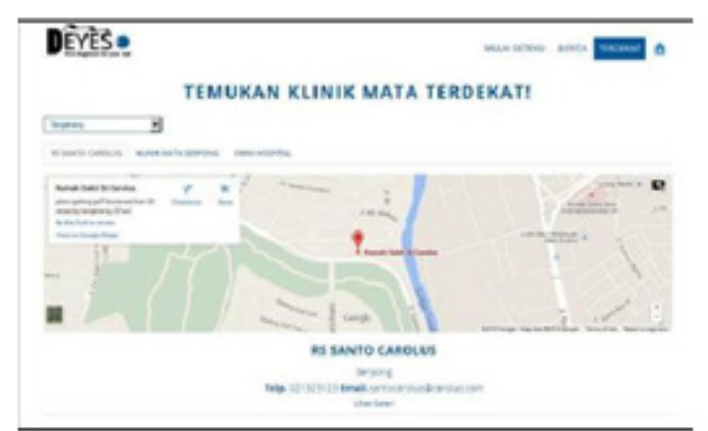

Gambar 14. Tampilan setelah memilih lokasi pada halaman nearby

\section{B. Backend}

Untuk masuk ke dalam halaman backend, user harus melakukan login terlebih dahulu. Apabila user melakukan login dengan benar, maka langsung masuk ke halaman home dari website sesuai dengan otoritas yang user miliki. Terdapat dua (2) otoritas user pada website ini yaitu admin dan doctor. Apabila user memiliki otoritas sebagai admin, maka user dapat melihat tampilan halaman home seperti pada Gambar 16.

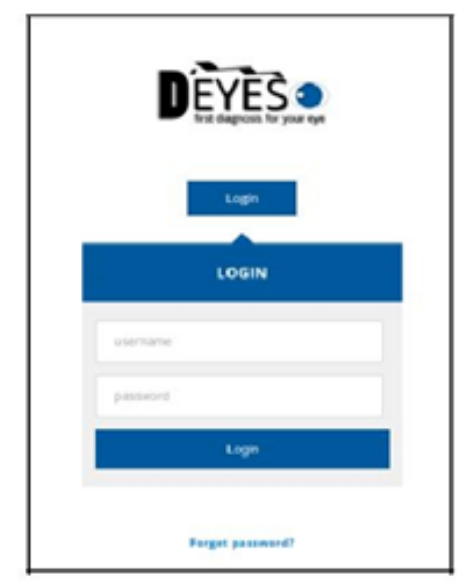

Gambar 15. Halaman login backend website

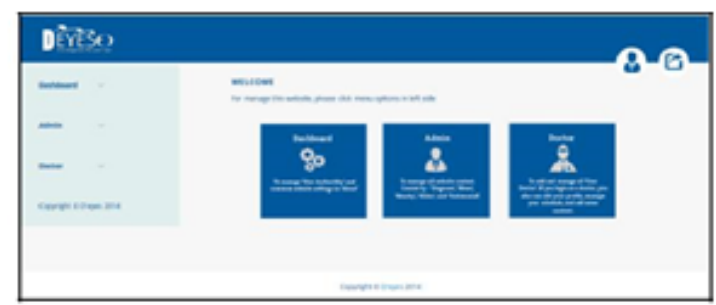

Gambar 16. Halaman home dari backend untuk user dengan otoritas admin
Sementara, apabila user memiliki otoritas sebagai doctor, maka user dapat melihat tampilan halaman home seperti pada Gambar 17.

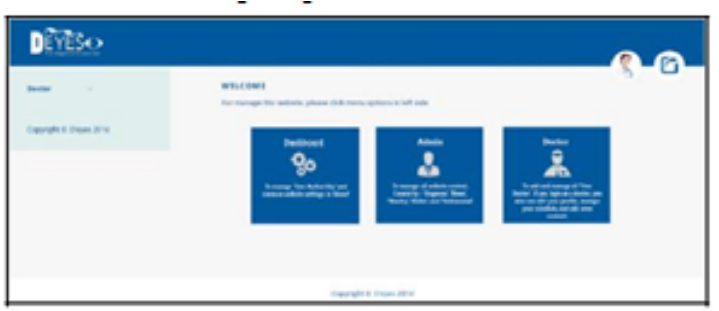

Gambar 17. Halaman home dari backend untuk user dengan otoritas doctor

\section{Uji Fungsionalitas}

Pada pembangunan sistem ini set-data yang digunakan berupa data pasien yang telah melakukan deteksi mata. Data ini didapatkan dengan membuat sebuah form diagnosa yang berisi pernyataan dan jawaban yang berhubungan dengan penyebab dan gejala katarak. Seluruh form tersebut diisi langsung oleh pakar yang terlibat.

Pakar yang terlibat pada penelitian ini adalah dokter spesialis mata. Terdapat tiga (3) dokter spesialis mata yang turut membantu pada penelitian ini, yaitu: Dr. Melissa Yulita Sp.M sebanyak 67 form, Dr. Cynthia Sp.M sebanyak 60 form, dan Dr. Budi Suryanto Sp.M sebanyak 50 form. Total seluruh form adalah 177 form. Setelah form terkumpul, selanjutnya dilakukan pengolahan berdasarkan tahapan KDD. Tahapan tersebut adalah:

1. Selection

Data yang masuk ke tahap berikutnya sebanyak 150 data.

2. Preprocessing

Data yang terseleksi digabungkan menjadi sebuah file berekstensi comma separated value (.csv).

3. Transformation

Pada tahap ini dilakukan langkah-langkah sebagai berikut pada sistem:

a. Masuk ke sistem sebagai user admin, 
b. Pilih side-menu 'Admin'> pilih sub-menu 'Diagnose'> pilih menu 'Training',

c. Klik button 'Add New Training Set', setelah itu akan berpindah ke halaman 'New Training Set',

d. Klik 'Browse'> pilih file dengan format .csv yang sudah dibuat sebelumnya $>$ klik button 'Confirm'.

4. Data Mining

Setelah semua data training sudah terupload, selanjutnya dilakukan penerapan metode decision tree.

5. Interpretation/ Evaluation

Setelah melewati proses mining, maka ditemukanlah pola dari decision tree seperti pada Gambar 18. Dalam gambar 18, terlihat bahwa atribut pandangan mata kabur (cloudy vision) menjadi akar (root) dari pohon tersebut. Sementara beberapa atribut lainnya ada yang digunakan sebagai percabangan, ada yang tidak.

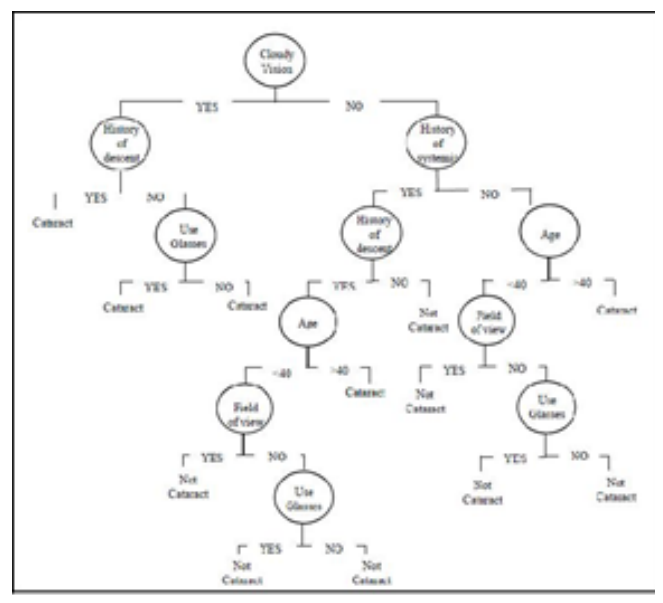

Gambar 18. Halaman home dari backend untuk user dengan otoritas doctor

\section{Analisis Hasil Uji}

Jumlah set data yang digunakan pada sistem ini adalah 150 dan angka $k$ yang digunakan pada sistem ini adalah 10. Jadi di setiap fold terdapat 15 set-data sebagai data testing dan 135 set-data sebagai data training.
Setelah 10-fold cross validation telah selesai dilakukan, maka selanjutnya adalah mencari nilai rata-rata dari nilai akurasi yang telah didapat tersebut. Nilai akurasi pada penelitian ini dibagi menjadi dua jenis, yaitu nilai akurasi result beserta type dari katarak dan nilai akurasi result saja. Perbedaan nilai akurasi keduanya dapat dilihat pada Tabel 1.

Tabel 1. Rata-rata nilai akurasi output sistem dengan 10-fold cross validation

\begin{tabular}{|c|c|c|}
\hline Fold ke- & $\begin{array}{c}\text { Nilai Akurasi } \\
\text { (Result-Type) }\end{array}$ & $\begin{array}{c}\text { Nilai Akurasi } \\
\text { (Result) }\end{array}$ \\
\hline 1 & $60 \%$ & $80 \%$ \\
\hline 2 & $73 \%$ & $80 \%$ \\
\hline 3 & $86 \%$ & $100 \%$ \\
\hline 4 & $73 \%$ & $93 \%$ \\
\hline 5 & $73 \%$ & $100 \%$ \\
\hline 6 & $80 \%$ & $93 \%$ \\
\hline 7 & $80 \%$ & $86 \%$ \\
\hline 8 & $80 \%$ & $100 \%$ \\
\hline 9 & $100 \%$ & $100 \%$ \\
\hline 10 & $100 \%$ & $100 \%$ \\
\hline Rata-rata & $80.5 \%$ & $93.2 \%$ \\
\hline
\end{tabular}

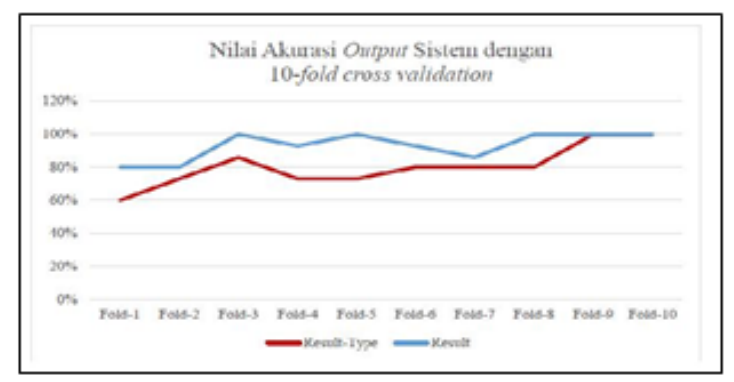

Gambar 19. Nilai akurasi output sistem pada uji 10-fold cross validation

\section{SIMPULAN DAN SARAN}

\section{A. Simpulan}

Simpulan yang dapat didapat dari penelitian yang telah dilakukan adalah:

1. Sistem pakar untuk mendeteksi adanya penyakit mata katarak secara dini, sudah berhasil dibangun. Sistem ini berbasis website, dengan mengimplementasikan algoritma $\mathrm{C} 4.5$ dari metode learning decision tree.

2. Sistem pakar ini dibangun berdasarkan datadata yang didapatkan dari form diagnosa 
yang telah dikumpulkan dari dokter spesialis mata.

3. Berdasarkan hasil uji yang telah dilakukan dengan menggunakan 10-fold cross validation didapatkan nilai akurasi type output sistem sebesar $80.5 \%$, sementara nilai akurasi dari result output sistem sebesar 93.2\%.

\section{B. Saran}

Saran yang dapat disampaikan bagi penelitian selanjutnya adalah:

1. Dalam penelitian selanjutnya, dapat digunakan lebih banyak lagi set-data yang bervariasi pada data-training dalam membangun decision tree.

2. Dalam penelitian selanjutnya, dapat digunakan algoritma lain dari metode decision tree seperti algoritma C5.0. Dapat juga diterapkan metode learning lain seperti Neural Network karena metode diprediksi memiliki nilai akurasi kedua terbesar setelah metode decision tree [4].

3. Sistem ini dapat dikembangkan untuk dapat mendeteksi penyakit mata lainnya atau melakukan klasifikasi jenis seluruh penyakit katarak yang ada.

\section{DAFTAR PUSTAKA}

[1] World Health Organization (WHO). Priority Eye Diseases [Online]. Available at: http://www.who. int/blindness/causes/ priority/en/inde x1.html [Accessed 24 April 2014].

[2] World Health Organization (WHO). Global Data On Visual Impairment [Online]. Available at: http://www.who.int/ blindness/publications/ globaldata /en/ [Accessed 11 February 2015].

[3] Badan Penelitian dan Pengembangan Kesehatan Kementrian Kesehatan RI. 2013. Riset Kesehatan Dasar. Jakarta.

[4] Hastuti, Khafiizh. 2012. Analisis Komparasi Algoritma Klasifikasi Data Mining Untuk Prediksi
Mahasiswa Non-aktif. Seminar Nasional Teknologi Informasi \& Komunikasi Terapan. Semarang, 23 Juni 2012, hal.241-249.

[5] Suyanto. 2014. Artificial Intelligence: Searching, Reasoning, Planning dan Learning. Bandung: Informatika Bandung.

[6] Rich, E. dan Knight, K. 1991. Artificial Intelligence. 2nd Edition. New York: Mc-Graw-Hill.

[7] Patterson, D. 1990. Introduction to Artificial Intelligence and Expert Systems. USA: Prentice Hall.

[8] Arhami, Muhammad. 2006. Konsep Dasar Sistem Pakar. Jilid 1. Yogyakarta: Penerbit Andi.

[9] Turban, E. 1995. Decision Support System and Expert Systems. 4th Edition. USA: Prentice Hall International.

[10] Hermawati, Fajar Astuti. 2013. Data Mining. Yogyakarta: Penerbit Andi.

[11] Larose, Daniel T. 2005. Discovering Knowledge in Data: An Introduction to Data Mining. John Willey \& Sons, Inc.

[12] Prasetyo, Eko. 2012. Data Mining Konsep dan Aplikasi menggunakan MATLAB. Yogyakarta: Penerbit Andi.

[13] Basuki, A. dan Syarif, Iwan. 2003. Modul ajar Decision Tree. Surabaya: PENS-ITS.

[14] Quinlan, J.R. 1992. C4.5: Programs for machine learning. San Mateo, California: Morgan Kaufmann Publishers.

[15] Ilyas, Sidarta, dkk. 2002. Ilmu Penyakit Mata: Untuk Dokter Umum dan Mahasiswa Kedokteran. Edisi kedua. Jakarta: Sagung Seto.

[16] Ilyas, Sidarta. 2001. Penuntun Ilmu Penyakit Mata. Edisi Kedua. Jakarta: Balai Penerbit FKUI. 
[17] Adriansah, Muhammad Akbar. Karakteristik Penderita Katarak di Puskesmas Ciputat Tahun 2006-2010 [Skripsi]. Jakarta: UIN Syarif Hidayatullah. 2011.

[18] Ilyas, Sidarta. 1989. Masalah Kesehatan Mata Anda dalam Pertanyaan-pertanyaan. Jakarta: Balai Penerbit FKUI.

[19] Breiman, L., Spector, P. 1992. Submodel Selection and Evaluation in Regression. The X-Random Case. International Statistical Review, Vol. 60 No. 3, December, hal. 291-319.

[20] Hastie, T., Tibshirani, R., dan Friedman, J. 2008. The Elements of Statistical Learning: Data Mining, Inference, and Prediction. 2nd Edition. Stanford, California: Springer.

[21] Pressman, Roger S. 2010. Software Engineering: A practitioner's Approach. 7th Edition. New York: McGraw-Hill. 